\title{
MORE LIGHT UPON THE PROBLEM OF THE OYSTER'S NUTRITION?
}

\author{
BY \\ Dr. P. KORRINGA \\ Bergen op Zoom, Holland \\ Biologist in the Government Institute for Fishery Investigations
}

\section{INTTRODUCTION}

Modern oyster culture began its development in the second part: of the nineteenth century. Beginning in Europe it gradually spread over all the world's oyster regions. Locally oyster cultural methods acquired a high degree of technical specialisation, recently even including chemical control of oyster diseases.

A steadily increasing stream of scientific and technical papers, dealing with oyster biology and oyster culture, accompanied this development, and already numbers several thousands of publications. If closely related industries, such as cattle-breeding, horticulture, and agriculture, are compared with it, it is clear that one of the basic problems of oyster culture must be the oyster's nutrition. Without a detailed knowledge of this subject it seems hardly possible to control effectively the oyster's growth and fattening. Therefore it will surprise many to learn, that two of the most prominent of our oyster biologists summarize their knowledge about this subject.as follows:

"At present we must confess our ignorance of the principles of mollusc nutrition and consequently our inability to suggest a practical solution of the problem of forced feeding and production of fat oysters at will." (GaLtsofF 1942).

"May I admit with complete candor and humility, that even after half a century of research on the oyster we are still not in a position to say with certainty just what this molluse can of cannot use as food?" (NELSON 1947).

I am sure that many of the earlier investigators, who thought this problem had been settled, would have been surprised to hear this too.

What is the reason of this hitherto unsatisfactory result of the many investigations? For the solution of the nutrition problem seems suite simple at first sight:

I. Ascertain what the oyster eats; 
2. Study the oyster's digestion;

3. Put the oyster on an artificial diet.

Although these three points are dealt with in a literature far too extensive to review adequately in a short paper, Galtsoff and Nelson's statements, quoted above, certainly do not express too pessimistic a view. This field is full of a multitude of controversies and paradoxes.

\section{THE STOMACH CONTENTS OF THE OYSTER}

Many investigators have tried to find out what the oyster eats, by examining its stomach contents. Often only a few diatoms could be recognised, which led to the wide-spread belief that diatoms are the oyster's most important food elements. Among those who supported this conclusion, be it with a greater or lesser degree of conviction, we mention MAC CRADY (1874), Lotsy (1895), Redeke (Hoek 1902), Heymann (19i4), Savage (I925), and Nelson (IO2I, I94I). Some authors claim that dinoflagellates, algal zoospores or still smaller organisms can be a very important source of food, MARTIN (1923,1927), Nelson (1925), CoE and Fox (1942). But only occasionally is it believed that animal food can be eaten in large amounts by Lamellibranch molluscs (Mansour-BeK 1946). Only a few of all these investigators frankly state that the organisms recognized by them constituted only a small fraction of the oyster's stomach contents (about 2 to $7 \%$ according to SAvage). The remainder could not be recognized and is considered to be, at least partly, finely divided organic detritus. This often led to the conclusion that this detritus forms the principal food, (Petersen (igi I), Moore (I9I3), BleGVAD (I9I4), COE and Fox (I944), and it has even been stated that living phytoplankton is of no importance at all as food to the oyster.

Detailed investigations revealed that oysters and related animals collect all the particles below a certain size by straining the water with the aid of their ef fective and intricate gill-apparatus. Particles which are too large or too spiny can be refused. As a rule, all the remainder, including indigestible silt, fresh or old organic detritus, and micro-organisms, is ingested. There is a great variation, however, in the relative proportions in different oyster regions, and in different seasons. This finally led to the conclusion, that one ought to be very careful indeed in one's deductions when considering the oyster's stomach contents, for certainly ingestion does not necessarily imply digestion.

\section{DIGESTIVE PROCESSES OF THE OYSTER}

Pioneers in this field were Chatin (1896), who described the different types of phagocytes in the oyster, and Heymann (I911, 1914), who was the first to identify the enzymes the oyster can make use of in its digestive processes. Blegvad's finding (19I4) that dinoflagellates like Prorocentrum micans can pass through the oyster's gut without being digested, has often been 
corroborated by other investigators. At present YoNGE (e.g. 1926, 1926a, 1943, 1946) is considered to be the leading authority in this field. He corroborated Vonk's studies (1924) on phagocytic digestion in the oyster, and concluded after lengthy and detailed investigations, that the great majority of Lamellibranch molluscs should be classed among the specialised herbivores. In the stomach carbohydrate-splitting enzymes, produced by the style, greatly preponderate. This has been confirmed by Sawano's findings (r929). Yonge claims that apart from the action of the style enzymes, digestion is exclusively intracellular in Lamellibranchs. The digestive diverticula are the site of this intracellular digestion and of absorption. Strong proteolytic and lipolytic action takes place only within the phagocytes. CoE and Fox (1942, 1944) and CoE (I945, I947) corroborated YongE's conclusions. They recorded that no evidence of the digestion of cellulose could be obtained. They repeatedly observed that great numbers of intact algal cells (e.g. the cellulose-walled dinoflagellates) are present in the faeces of oysters and mussels. LoosanofF (1947) demonstrated that plankton organisms are often still quite viable after passing undamaged through the oyster's gut. CoE included among the indigestible substances all living cells and organisms which are too large for intracellular digestion. Minute diatoms are readily digested (intracellularly), for COE demonstrated the presence in the facces of a multitude of chloroplasts with only a few intact cells after feeding his mussels with pure cultures of such minute species. COE also states that there can be no doubt that finely divided organic detritus furnishes a large proportion of the nutriment of all filter feeders. We must leave undecided which constituents of the detritus are digestible. Certainly minute fragments of the old peat-soil in the Oosterschelde (Holland), forming the bulk of the local detritus, have little or no value as food.

The prevalence of intracellular digestion in the majority of Lamellibranch molluscs has recently been questioned. First it has been claimed by NeLson (1933) that Yonge underestimated the power and the importance of the style enzymes in extracellular digestion in the oyster. Large diatoms like Coscinodiscus, Melosira, and Skeletonema were frequently encountered in the stomach of Ostrea virginica in a state of disintegration. He considered this to have been brought about by digestion, which must have taken place extracellularly. Chestnut (1946) even states that such diatoms appear to be subject to digestion during part of the tidal cycle, and at other times they are not (Ostrea virginica). Mansour (I946, I946a) and Mansour-BeK (I946, I946a) believe that animal plankton constitutes a much greater part of the food of Lamellibranchs than is generally accepted, and that this fact has often escaped other investigators' attention owing to the very rapid digestion of this animal food. They claim to have demonstrated the presence of proteolytic and lipolytic enzymes in the stomach of Tridacna and Pinctada. Observations in vitro did not confirm such: strong action of extracellular proteolytic enzymes as is required to bring about the very quick rate of digestion of animal plankton 
they believe in. YoNGE (1946), in defending his view, partly withdrew, and said that objects too large for intracellular digestion could be digested by phagocytic blood cells which could pass in great numbers into the lumen of the digestive tract. These phagocytes are believed to be able to execute an attack in mass upon certain larger objects and to digest those by excretion of proteases and lipases. This phenomenon could at the same time account for the presence of some proteolytic and lipolytic enzymes in the stomach juice. YoNGE adds: "Possibly the presence of animals in the stomach stimulates migration of phagocytes inta the lumen". COE (1947) is inclined to share YONGE's view in this respect too.

Nothing is settled at present. Intracellular digestion certainly is of the greatest importance, but extracellular digestion seems possible, at least of organisms without a cellulose covering. We do not know to what degree this is the case, what the size limit is, what external conditions are necessary, nor whether different Lamellibranchs show the same behaviour in this respect.

\section{FEEDING EXPERIMENTS}

The results of feeding oysters on an artificial diet have been extremely poor so far. As a rule oysters sooner or later starve or die in the laboratory. Normal growth and fattening has rarely been obtained under artificial conditions.

MARTIN (1927, 1928), fed his oysters with pure cultures of plankton organisms, but they showed only a very poor growth. Naked nannoplanktic organisms appeared to be quite suitable as food. The little known experiments of GAVARD (1927) represent the only case of an almost normal growth in vitro, his oysters showing an increase in weight of about ${ }_{5} \mathrm{KG} / 1000$ / season. These experiments demonstrate that oysters can do without living organisms as food. Gavard used as food an artificial detritus prepared from animal or plant material. Loosanoff and ENGLE (1944, I947) tried to fatten oysters by feeding them with thick cultures of plankton organisms, but observed to their surprise that their oysters showed signs of starvation in the midst of this plenty. They demonstrated that the metabolic products of the micro-organisms used are inimical to the oyster if present in too large quantities, so that their oysters could not feed normally under the experimental conditions. It goes without saying that efforts to fatten oysters in the open, like those of FolPMERS (1919, I921), who tried by adding fertilizers to raise locally the number of bottom diatoms, considered then to be so important as a food for oysters, were too far ahead of his time to warrant success.

\section{THE MECHANISM OF THE GILL-APPARATUS}

Much has been written on the structure and function of the oyster's gillapparatus, which strains the water so efficiently in collecting food. Many 
details of its structure can be found in AtKIns' papers (1936-1938). ElsEY (1935) gives many interesting details about the gill-apparatus of Ostrea gigas and Ostrea lurida.

Many investigators have tried to find out how much water is filtered by the gill-apparatus per unit of time. They used different methods. In the muchquoted experiments conducted by ViallaNès (1892) he estimated how much time it took Ostrea edu!'is, Gryphaea angulata, and Mytilus edulis to clear up water made turbid with a suspension of clay, from which he concluded, that the filtering power of Ostrea edulis remains far behind that of the mussel and the Portuguese oyster. Fox et al. (1937) used this same method, adding a suspension of calcium carbonate to the water, from which experiments they concluded that the California mussel pumps rhythmically $2 \frac{1}{2}$ liter of water per hour.

In another method, described by GaLtsoff (1926), and called the carminecone method, the water from the oyster's exhalent chamber is led into a glass tube, and by adding at intervals carmine into the tube, the rate of flow could be computed. Later Galtsoff (1928) described an "overflow chamber" into which all the water leaving the oyster's exhalent chamber could be led, so that it could be measured accurately. This method later led to the construction of an ingenious self-registering apparatus, which records every drop of water passing through the oyster's gills. This apparatus is frequently made use of to measure the oysters filtration under different conditions. Thus it was used in the feeding experiments of LoOSANOFF and ENGLE mentioned above (1944, 1947, 1947a) and in studying the effects of noxious or presuma. bly toxic substances on the oyster's activities (GALTSOFF 1947). Estimates have of ten been made of the temperatures at which the gills pump most actively and those at which pumping comes to a standstill (e.g. GaltsofF I926, I928, Hopkins 1933, 1935).

One of the most important results of this kind of investigation was the demonstration that shell-movements are not a reliable measure of the oyster's feeding activities. Often no current of water is produced even when the shells are open. This greatly diminishes the value of earlier investigations (e.g. Nelson 1923) in which shell movements were reconded to study the oyster's feeding activities.

All the investigators mentioned above presume that it is the intricate gillapparatus itself which is used as an ideal and efficient filter during feeding. The water is thought to be drawn through the narrow gill-slits (ostia) by a well-co-ordinated ciliary action, while the food particles are caught because they cannot slip through. Afterwards the food is "consolidated" by mucus, amply secreted on the gills, and carried towards the mouth by ciliary action (c.f. Yonge 1938, Yonge and Iles 1939).

Bijdragen tot de Dierkunde, Afl. 28. 


\section{MACGINITIE'S FINDINGS}

Studying the behaviour of Urechis, MacGinitie found (1937) that this Echiuroid worm steadily draws a stream of water through its burrow and strains out the food particles with a mucous feeding net: After some time the net is eaten with all the objects it has caught, and a new net is secreted in the burrow. The slime net proved fine enough to trap the smallest particles which are visible with the aid of an oil immersion lens. Later (I945) MacGinitie used solutions of coloured proteins to measure the size of the meshes of the mucous feeding net, and came to the remarkable conclusion that it could safely be said that in Urechis and Chaetoptera the meshwork openings in a mucous feeding net are of a magnitude between $36 \mathrm{~A}^{\circ}$ and $90 \mathrm{~A}^{\circ}$, as a rule $40 \mathrm{~A}^{\circ}$. Large protein molecules could easily be caught by Urechis' nets. With good reason MAcGinitie states: "One is impressed with the efficiency of mucus as a net for straining food from water." "The molecular size of decomposition products would preclude their use as food material, but all other organic materials, including protein molecules of a size greater than $40 \mathrm{~A}^{\circ}$ could be used." MacGinitie found that in the case of many other animals in which the cilia have been credited the selective function of obtaining food, this work is actually performed by mucous sheets through which the water is strained, and actually the cilia on the gill-apparatus furnish only the mechanical power for creating the currents. MACGinitie (I94I) demonstrated that this is the case in Lamellibranch molluscs, including the oyster. A sheet of mucus entirely covers the gill structure during active feeding, and it is this thin mucous which strains out food material from the water. "Cilia serve only to create the current and move the mucus." The food-laden mucous sheets are transported to the mouth. By a clever device he could actually see what happened within the intact mollusc during feeding. These animals are very easily disturbed and upset. Mucous feeding then comes to a standstill, often for prolonged periods, though the pumping of water may go on. Feeding carmine grains or even carborundum, as has so often been done in laboratories all over the world, gives a very unreliable picture of what really happens during normal feeding. The cilia may go on doing their work, but no mucous feeding takes place under such crude and inadequate conditions. Only the coarser particles, unable to pass through the gill-slits are caught then. MacGinitie concludes that "it is unwise to speak of feeding in a pelecypod, unless it is actually observed doing so". "Certainly it never should be said that a pelecypod is feeding just because it is pumping or maintaining a current through the mantle cavity."

\section{NEW LIGHT UPON OLD CONTROVERSIES AND PARADOXES?}

MACGinitie's far-reaching findings have not yet attracted the attention they deserve. In my view his discoveries throw light upon several other problems of the oyster's nutrition: 
I. In a tank breeding experiment carried out at Tholen (Holland), 1946, I observed a remarkably rapid recovery and fattening of the breeding oysters. The water in the tank contained neither diatoms nor detritus, but was a practically pure culture of minute naked flagellates, measuring about 3 to $4 \mu$ and numbering approximately 50.000 per cc. Obviously the oysters fed on these. flagellates, though they are far too small to be retained by the oyster's gillslits, which are from 40 to $60 \mu$ wide. MacGinitie's mucous feeding sheet explains how the oyster manages to catch the flagellates.

2. It has repeatedly been reported that oysters are able to strain bacteria from the water they draw through the gills. ZoBell and LANDon (I937) even proved hat oysters can catch $99.9 \%$ of the bacteria introduced into the water. On the other hand ELSEY (I935) tells us that the ostia (gill-slits) in a pumping oyster are from 45 to $60 \mu$ wide in Ostrea lurida, and in Ostrea gigas only about $1 / 3$ less. If one considers the gill-apparatus to be the oyster's straining mechanism these facts are an obvious paradox. Curiously enough neither ELSEY nor other workers in this field seemed to be aware of this discrepancy. MACGinitiE's findings solve this mystery at once.

3. LoosAnOFF and ENGLE (1947) investigated what percentage of organisms fed to their oysters was retained by the gills. In feeding with Chlorella cultures they found that the percentage retained varied for no apparent reason from 0 to $92 \%$. They did not find an adequate explanation for this observation. GALTSOFF (1928) found similar differences in feeding bacteria to oysters. We understand now that the difference is due to the absence or presence of a mucous sheet during pumping. This means that Loosanoff's premise "the quantity of water leaving the oyster can be measured, thus the rate of pumping and, therefore, feeding can be estimated", obviously does not always hold good. We should say with MacGinitie "certainly it never should be said that a pelecypod is feeding just because it is pumping or maintaining a current through the mantle cavity." We should add, however, that Loosanoff's important findings regarding the effect of phytoplankton metabolites on the rate of pumping are not affected by this criticism. Only where pumping has been mistaken for feeding the conclusions should be considered with the greatest care. The same holds good for Galtsoff's investigations on the influence of toxic substances on the oyster (1947).

COE and COE and Fox, in their detailed study of feeding and growth in the California mussel, repeatedly say, in considering the quantity of water filtered, that the organisms present in the water, even if they could be totally digested (which they certainly cannot) constitute only a small fraction of the mussel's actual requirements. The number of diatoms is quite low at la Jolla, and the dinoflagellates there number 30 per $\mathrm{ml}$. on an average. Bacteria can constitute but a minute fraction of the mussel's nutritive requirements (CoE I945).

It seems probable that the remainder is obtained from the smaller particles, 
animate or inanimate. The quantity of particulate organic detritus too small to be seeen with a microscope, but which can easily be caught by the mucous feeding sheet, has never been ascertained in coastal water. All we know is that the total amount of "dissolved" organic matter there often exeeds that present in plankton organisms by about to times.

COE and his co-workers always give the number of dinoflagellates, cellulosewalled organ:sms of about 20 to $30 \mu$ in diameter. They never inform us about the much smaller "naked" flagellates, devoid of cellulose. In two consecutive seasons I regularly estimated the number of small naked flagellates in the Oosterschelde. They were present in numbers from 1000 to 8000 per ml. throughout the year, while small diatoms seldom amounted to more than 5 per $\mathrm{ml}$., larger diatoms in the net-plankton being far rarer still. The number of dinoflagellates proved to be insignificant. I hope to deal with these data and the methods used in a separate paper in the near future. I am inclined to believe that after finely divided organic detritus, small naked flagellates, measuring from 2 to $4 \mu$, are of great importance as food, not only to the oyster larvae, but also to adult oysters.

Nelson (1942) ascribes a rapid fattening of oysters to a flourishing diatom flora (Skeletonema) caused by an ample supply of fresh water rich in nutrients. Nelson did not produce conclusive evidence that only diatoms flourished and that nannoplanktonic flagellates and also finely organic detritus were not present in enormous quantities at the same time, so that doubt remains whether the fattening of his oysters is really due to diatoms.

5. Ranson (1927) claims that the little diatom Navicula ostrearia, flourishing in the French "claires" produces a green pigment, which dissolves in the water and becomes absorbed by the oyster. The diatoms themselves he supposes not to be eaten by the oyster in appreciable quantities. Ranson did not adduce conclusive evidence for his theory that the pigment is directly absorbed by the oyster's gills.

In the light of MacGinitie's findings we should like to know the size of the "particles" of green pigment "dissolved" in the water. Ranson himself speaks of "substance huileuse sous forme de gouttelettes". It does not seem impossible that the oyster can collect the minute droplets with its mucous sheets. We even wonder whether such material might not form the bulk of the oyster's food in the claires.

6. Inevitably we come up against the old controversy whether or not dissolved organic matter can be used as food by marine organisms. PürTer (e.g. I909, I9II) once argued ardently that it could, but the matter is generally thought to be settled with KroGH's conclusion (I93I): "There is no convincing evidence that any animal takes up dissolved organic substance from natural water in any significant amount."

Before the arguments are brought forward again, we should consider what we mean by "dissolved" organic matter. Are particles of about $40 \mathrm{~A}^{\circ}$, too 
small to be seen by a microscope "dissolved"? In the light of MacGinitie's findings our ideas on this point should be reconsidered. Experiments with glucose as dissolved organic matter (YoNGE 1928) will not yield the same results as when the larger molecules of proteins are used, large enough to be caught by the mucous feeding nets.

If we really come to the conclusion, following CoE's calculation, that very finely divided organic matter and nanno-plankton organisms smaller than Io $\mu$ form the bulk of the food of Lamellibranchs, argument about extracellular digestion would lose much of its importance, since intracellular digestion would be predominant, at least in coastal waters rich in detritus and flagellates.

8. The question of "concurrence vitale", the mutual competition between different filter feeders living in the same area, should be reconsidered in the light of MacGinitie's discovery (Ranson I926, I939, Borde and Borde 1938, LAMBERT 1946). Hitherto the quantity of water pumped has been considered a measure of the feeding capacity of a filter feeder. Is it not possible that different species specialize on particles of a definite size?

In this connection it is interesting to hear that WaLshe (1947) found that the larvae of Chironomus make use of a mucous feeding net through which particles smaller than I $2 \mu$ can pass. We are anxious to learn more about the size of the meshes used by different plankton strainers. Perhaps this will provide a reason for the remarkable fact that an increase in the number of oysters repeatedly led to a poor quality of the oyster (KoRRINGA 1947), while the presence of large numbers of mussels or Crepidulas did not interfere perceptibly with the oyster's fattening.

\section{SUGGESTIONS FOR FUTURE WORK}

Next to measuring precisely the size of the meshes in the mucous network of filter feeders, we should like to begin feeding oysters on a controlled diet. If I were to carry out such investigations, I would choose a couple of good claires, where oysters grow and fatten satisfactorily owing to plentiful food. I should feed oysters with water taken regularly from the claires, where the controls should be kept, under exactly the same external conditions, but I should try to separate the organic matter, both animate and inanimate, according to the size of the particles. Perhaps this could be done with the aid of filters and dialysis. Thus each group of experimental oysters would receive only organic nutrition between very definite size limits. My objection to GAVARD's experiments is that he offered his oysters detritus particles of all possible dimensions, down to dissolved organic matter, so that we still do not know which size of food the oyster prefers. It would be interesting to repeat GAVARD's work with definite quantities of the same food material of several definite size classes. 
Only ofter all these problems have been solved may we hope to find a practical solution of the problem of artificial feeding and the production of fat oysters at will.

\section{LITERATURE}

Atkins, D., 1936-1938. On the ciliary mechanisms and interrelationships of Lamellibranchs. Quart. Journ. Micr. Sci., LXXIX, 181-308, 339-373, 375-421, 423-445; LXXX, 321, 33I, 345 .

Blegvad, H., 19I4. Food and conditions of nourishment among the invertebrate animals found on or in the sea bottom in Danish waters. Rep. Dan. Biol. Stat. XXII.

BORDE, F. and BORDE, J., 1938. Ostrea edulis et Gryphea angulata. Caractères communs et caractères differentiels. Rev. Trav. Pêches Mar., XI, 503-5I4.

Chatin, J., I8g6. De la phagocytose chez les huitres. C. R. Acad. Sci. Paris, CXXII, 487-490.

Chestnut, A. F., 1946. Some observations on the feeding of oysters with special reference to the tide. Convention addresses meeting Nat. Shellfish. Ass. New York, June 5-7, 22-27.

CoE, W. R., 1945. Nutrition and growth of the California bay-mussel (Mytilus edulis diegensis). J. Exp. Zool. XCIX, I-I4.

-, 1947. Nutrition, growth and sexuality of the Pismo clam (Tivela stultorum). J. Exp. Zool., CIV, I-24.

-, and Fox, D. L., 1942. Biology of the California sea-mussel (Mytilus californianus). I. Influence of temperature, food supply, sex and age on the rate of growth. J. Exp. Zool., XC, I-30.

—- - 1944. Biology of the California sea-mussel (Mytilus californionus). III. Environmental conditions and rate of growth. Biol. Bull., LXXXVII, 59-72.

ELSEY, C. R., 1935. On the structure and function of the mantle and gill of Ostrea gigas (Thunberg) and Ostrea lurida (Carpenter). Trans. Roy. Soc. Canada, XXIX, $13 \mathrm{I}-158$.

FolpMERS, T., 1919-1921. Rapport van des Bestuurs bacterioloog, betreffende kunstmatige voeding van oesters. Tweede rapport van des Bestuurs bacterioloog, betreffende de proeven met kunstmatige voeding van oesters in het jaar 1920. Bergen op Zoom.

Fox, D. L., Sverdrup, H. U. and Cunningham, J. P., 1937. The rate of water propulsion by the Californ:a mussel. Biol. Bull. LXXII, 417-438.

Galtsoff, P. S., 1926. New methods to measure the rate of flow produced by the gills of the oyster and other molluscs. Science, LXIII, 233-234.

- I928. Experimental study of the function of the oyster gills and its bearing on the problems of oyster culture and sanitary control of the oyster culture and sanitary control of the oyster industry. Bull. U. S. Bur. Fish., XLIV, 1-39.

- 1942. Problems of productivity of oyster bottoms. Address Nat. Shellfish. Ass., Philadelphia Meeting June 1942, 7 pp.

-, Chipman, W. A., Engle, J. B. and Calderwood, H. N., 1947. Ecological and physiological studies of the effect of sulfate pulp mill wastes on oysters in the York River, Virginia. Fish. Bull. Fish and Wildlife Service, LI, 59-186.

Gavard, 1927. De quoi se nourrissent les huitres? Leur nourriture envisagée au point de vue "Ostréiculture". Bull. Trav. Stat. Aquic. Pèche Castiglione Alger, I, 237-254.

Heymann, J. A., 191 I. Over enzymen in de oester. Handl. Ned. Nat. Geneesk. Congr., XIII, 215-226.

_-, 1914. Voeding der oester. 's-Gravenhage, Mouton, 132 pp.

HoEK, P. P. C., 1902. Rapport over de oorzaken van den achteruitgang in hoedanigheid van de Zeeuwsche oester. 's-Gravenhage, Ministerie van Waterstaat, I68 pp.

Hopkins, A. E., 1933. Experiments on the feeding behaviour of the oyster (O. gigas). J. Exp. Zool., LXIV, 469-494.

- 1935. Temperature optima in the feeding mechanism of the oyster (O. gigas). J. Exp. Zool., LXXI, 195-208. 
KorRingA, P., 1947. Les vicissitudes de l’ostréiculture Hollandaise élucidées par la science ostréicole moderne. Ostréiculture, cultures marines, XVI. No. 3, pp. 3-9.

KroGH, A., I93I. Dissolved substances as food of aquatic organisms. Rapp. Proc. Verb. Réunions Conseil Perm. Int. Expl. Mer, LXXV, 7-36.

LAMBERT, L., 1946. Les huitres des côtes françaises. La pêche maritime, la pêche fluviale et la pisciculture, XXIX, 31-33.

Loosanofr, V. L. and Engle, J. B., 1944. Feeding and fattening of oysters. Address Nat. Shellfish. Assoc., Meeting Atlantic City, June I944.

- - - 1947. Effect of different concentrations of micro-organisms on the feeding of oysters (O. virginica). Fishery Bull. U. S. Fish and Wildlife Service, XL, 3I-57.

- - - 1947a. Feeding of oysters in relation to density of micro-organisms. Science, $\mathrm{CV}, 2723$.

Lotsy, J. P., I895. The food of the oyster, clam and ribbed mussel. Rep. U.S. Fish. Comm. I893, 375-386.

MACCRADY, 1874. Observations on the food and on the reproductive organs of Ostrea virginica, with some account of Bucephalus cuculus. Proc. Boston Soc. Nat. Hist., XVI, $176-192$.

MacGinitie, G. E., 1937. The use of mucus by marine plankton feeders. Science N.Y., LXXXVI, 398-399.

- 194I. On the method of feeding of four Pelecypods. B:ol. Bull., LXXX, I8-25.

-, 1945. The size of the mesh openings in mucous feeding nets of marine animals. Biol. Bull., LXXXVIII, 107-111.

Mánsour, K., 1946. Food and digestive organs of Lamellibranchs. Nature, London, CLVIII, 378.

-, 1946a. Food and digestive processes of the Lamellibranchs. Nature, London, CLVII, 482.

- 1946b. The zooxanthellae, morphological peculiarities and food and feeding habits of the Tridacnidae with reference to other Lamellibranchs. Proc. Egypt. Acad. Sci., I, I-II.

Mansour-Bek, J. J., I946. The digestive enzymes of Tridacna elongata Lamk. and Pinctada vulgaris L. Proc. Egypt. Acad. Sci., I, I3-20.

-, 1946a. Extracellular proteolytic and lipolytic' enzymes of some Lamellibranchs. Nature, London, CLVIII, 378-379.

Martin, G. W., 1923. Food of the oyster. Bot. Gazette, LXXV, I43-169.

-, 1927. Enteromorpha and the food of oysters. Science, LXVI, 662.

—, I927a. Utilization of food by young oysters. New Jersey Agric. Exp. Stat. Bull. $442,12 \mathrm{pp}$.

-, 1928. Experimental feeding of oysters. Ecology, IX, 49-55.

Moore, H. F., 19Io. Volumetric studies of the food and feeding of oysters. Proc. 4th Int. Fish. Congr., Bull. Bur. Fish. Washington, XXVIII, 1295-1308.

-, 1913. Condition and extent of natural oyster-beds and barren bottoms of Mississippi east of Biloxi. Bureau of Fisheries Bull. 774.

Nelson, T. C., 1921. Report of the Department of Biology. New Jersey Agric. Exp. Stat. $1919-1920$.

-, 1923. On the feeding habits of oysters. Proc. Soc. Exp. Biol. Med. N.Y., XXI, co-9r.

-, I925. Report of the Department of Biology. New Jersey Agr. Coll. Exp. Stat. 1924. , 1933. On the digestion of animal forms by the oyster. Proc. Soc. Exp. Biol. N. Y., $\mathrm{XXX}, 1287-1290$.

—, I94I. Oysters. "Science and the land" I940-4I Annual Rep. New Jersey Agric. Exp. Stat., 108-110.

-, 1947. Some contributions from the land in determining conditions of life in the sea. Ecol. Monogr., XVII, 337-346.

Petersen, C. G. J. and Boysen-Jensen, P., i.gi i. Havets Bonitering, I. Havbundens Dyreliv, dets Næring og Mængde. Rep. Dan. Biol. Stat., XXII.

PÜTTER, A., 1909. Die Ernährung der Wassertiere under der Stoffhaushalt der Gewässer. Jena, Fisher. 
Pürter, A., 19r1. Die Ernährung des Wassertiere durch gelöste organische Verbindungen. Pflügers Arch. CXXXVII, 595.

RANSON, G., 1926. L'huître portugaise tend-elle à remplacer l'huître française? Notes Mem. Off. Sci. Techn. Pêches Mar. XLVII, 9 pp.

- 1927. L'absorption de matières organiques dissoutes par la surface extérieure du corps chez le ; animaux aquatiques. Annales Inst. Océanogr., IV, 49-175.

- 1939. Sur la prétendue concurrence vitale entre Gryphaea angulata Lmk. et Ostrea edulis L. Bull. Mus. Paris, XI, 569-573.

RYDER, J. A., I884. A contribution to the life history of the oyster (Ostrea virginica Gmelin and $O$. edulis Linn.). Fisheries and Fish. Industr. U.S., Wash., 7 $1 \mathrm{I}-758$.

SavaGe, R. E., 1925. The food of the oyster. Fish. Invest. Gr. Br. Ser. II, VIII, I-50.

Sawano, E., 1929. Studies on the digestive enzymes of Ostrea circumpicta. Sci. Rep. Tôhoku Imp. Univ. Sendai (4), IV, 327-334.

SpÄRCK, R., 1933. Some preliminary investigations on the power of filtration in Ostrea edulis. Rep. Dan. Biol. Stat. XXXVIII, 3I-32.

Viallanks, H., I892. Recherches sur la filtration de l'eau par les mollusques et applications à l'ostréiculture et à l'océanographie. C. R. Acad. Sci. Paris CXIV, r386-i 388 .

VonK, H. J., 1924. Verdauungsphagocytose bei den Austern. Zeitschr. Vergl. Physiol., I, $607-623$.

WALSHE, B., 1947. Feeding mechanisms of Chironomus larvae. Nature, London, CLX, 474.

YONGE, C. M., 1926. Structure and physiology of the organs of feeding and digestion in Ostrea edulis. Journ. Mar. Biol. Ass., XIV, 295-386.

-, 1926a. The digestive diverticula in the Lamellibranchs. Trans. Roy. Soc. Edinb., LIV, $703-718$.

-, 1928. The absorbtion of glucose by Ostrea edulis. Journ. Mar. Biol. Ass., XV, 643-654.

- I938. Evolution of ciliary feeding in the Prosobranchia with an account of feeding in Capulus ungaricus. Journ. Mar. Biol. Ass., XXII, 453-468.

-, 1943. Functional interpretation of molluscan structure. Proc. Malac. Soc., XXV, $132-135$.

-, 1946. Digestion of animals by Lamellibranchṣ. Nature, London, CLVII, 729.

- and E. J. ILEs, 1939. On the mantle cavily, pedal gland, and cvolution of mucous feeding in the Vermetidae. Ann. Mag. Nat. Hist., Ser. II, III, 536-556.

ZoBell, C. E. and Landon, W., 1937. Bacterial nutrition of the California mussel. Proc. Soc. Exp. Biol. Med., XXXVI, 607--609. 